\title{
Isayeva T.A.*
}

DOI: 10.25108/2304-1730-1749.iolr.2016.46.65-100

\section{Problems of evaluation of expert-psychologist's report}

Abstract: Evaluation of the evidences is mandatory element of proving process. It is concluded in result on reliability or unreliability of evidences and proof or nonproof of a fact containing in it.

There should be differentiated thinking activity on assessment of evidential information and thinking activity on evaluation of evidences in criminal procedural proving.

Determination of assessment subject takes a significant place in criminal procedural proving, i.e. features of evidential information or evidences.

At the stage of evaluation is made clear a matter whether received evidential information corresponds to criterion of pertinence and admissibility.

Inner conviction is an instrument of evidences' assessment on criminal case.

Evidential aspect is distinguished in matters of assignment of forensic psychological expert examination, whereas an expert-psychologist report has evidential value.

Keywords: criminal procedural proving; evaluation of evidences; expertpsychologist; forensic psychological expert examination; criterion of pertinence; criterion admissibility; moral certainty.

It seems that before beginning to consideration and analysis of evaluation's problems of an expert-psychologist report there is necessary to define them or to indicate what are contradictions between reality and declarative instructions, and then to seek the ways of their overcoming.

\footnotetext{
- Isayeva Tarana Abdulla qyzy - a dissertator of Institute for Philosophy, Sociology and Law of NAS Azerbaijan Republic, a member of IOLR (Azerbaijan). E-mail: mopi_sid@yahoo.com
} 
In our point of view, main problem and more exact, paradox in this is a fixed in CPC contradictions on necessity and possibility of help of specialists (experts) for resolution the matters, which require special knowledge and following evaluation of the results received through the knowledge by persons, who applied for help, i.e. they had no special knowledge and could not solve this issue themselves.

If to speak shorter, then we have a quibble: incompetent persons applied for help to competent ones, and after that they begin to judge about competence of the latter. But this is a half of trouble, if did not arise a question about legitimacy of incompetent court.

As it known, assessment of evidences is mandatory element of proving process and legislatively fixed in articles 33 and 138 of CPC, and also in article 145 of CPC, which establish the rules of evidences' evaluation [25, p. 26-27]. But, a lawmaker does not define a term "assessment of evidences" and in connection with this, definitions of considered notion having in scientific literature present an interest.

So, M.S. Strogovich asserted that "evaluation of evidences is concluded in determination of reliability or unreliability of evidence... and proof or non-proof of a fact containing in this evidence" [24, p. 303-304].

On opinion of most part of scientists, assessment of evidences is a thought activity of an investigator, prosecutor and judges, who guiding by law and legal sense, are considering on their moral certainty evidence in separate and all combination of evidences; and thus is determined their relevancy, admissibility, reliability and sufficiency for conclusions on a case $[1$, p. 91-92; 4, p. 90-91; 9, p. 40-42; 16, p. 9195].

Evaluation of evidences was considered by R.S. Belkin as a logic process to establish admissibility and relevancy of evidences for achievement of the truth $[3, \mathrm{p}$. 66-67].

According to I.M. Shemelev, assessment of evidences includes their admissibility, relevancy, reliability, force and sufficiency for conclusions [10, p. 91]. 
In compliance with definitions indicated, evaluation of evidences is presented to be thought activity, logic process, but under determination of core and subject of indicated assessment appears considerable disagreements.

So, in opinion of M.S. Strogovich, evaluation of evidences is a final, more complicated and responsible stage of proving [24, p. 302]. According to N.P. Kuznetsov, in course of proving there is inevitable a preliminary assessment of evidences during their collection and checking, therefore it is unsuccessful a definition of collection, checking, evaluation of evidences like the stages of proving process $[13$, p. 10].

Certain part of disagreements relatively to content of assessment of evidences in criminal process is related to a subject of such evaluation, but, in our point of view, before to speak about subject of evidences' assessment in criminal process there necessary to be defined with an object of such evaluation, as both evidences and evidential information are the objects of criminal procedural proving. Therefore, one should speak about evaluation of relevancy and admissibility of evidential information but not about assessment of relevancy and admissibility of evidences.

Consequently, in criminal procedural proving should be distinguished thought activity on assessment of evidential information and thought activity on evaluation of evidences, which is not the same.

There an important significance in analysis of indicated kinds of activity has a definition of subject of assessment, i.e. features of evidential information or evidences, availability of which is mandatory for solution of the objectives of criminal procedural proving.

In our views, a subject of evidences' assessment should be included the following features: relevancy, admissibility, reliability, significance (force) and sufficiency for conclusions.

A lawmaker reasonably included in a subject of evaluation all listed features of evidences in new criminal procedural law of 2000. According to article 145 of CPC, any evidence is subjected to assessment with point of view of relevancy (affiliation), 
admissibility and reliability, and all collected evidences in combination - sufficiency for resolution of criminal case [25, p. 165].

According to E.A. Snegirev, evidential information (evidences) should be recognized reliable if it: a) does not contradict other evidential information (evidences) received to this time of criminal proceedings; b) is correlated with a system of evidential base formed at certain stage of criminal proceedings, i.e. acts as a connecting chain between other evidences, which have in a case; c) is confirmed with other evidences, which have been formed to the time of criminal proceedings [22, p. 66-67].

I.G. Kraynov justly notes that if information received does not meet the criteria, it cannot be assessed as evidence, since establishing of the truth on criminal case as main goal of proving should be based on a system of internally agreed and mutually confirmed each other evidences. Otherwise, there have a place only a set of separated presuppositions, on basis of which is inadmissible to make any conclusions and moreover to take decisions, in which are realized the function of criminal proceedings $[11$, p. 90].

R.G. Ashkenazi points out that in a stage of evaluation is clarified whether evidential information received corresponds to criterion of relevancy, and is also determined whether evidential information possesses with feature of admissibility [1, p. 19-20].

According to E.A. Snegirev, criterion of admissibility reflects, first of all, formal requirements of criminal procedural law to regime of evidences' formation. Sufficiency of evidences should also be subjected to assessment in course of proving. Therefore it is necessary to distinguish an adequacy of evidential information for formation evidences from it and sufficiency of evidences for adoption procedural decisions on a case, and also sufficiency all collected evidences for resolution of criminal case [22, p. 91-92].

Article 146 of CPC says about sufficiency all collected admissible evidences on criminal prosecution, volume of which on subjected to establishment circumstances 
allows making a reliable total conclusion for determination of proving subject $[25, \mathrm{p}$. 165-166].

Despite clearness seemed, an issue on sufficiency of evidences, in our view, is also problematic. Since in different stages of court proceedings interconnected matters about adequacy evidences and completion of investigation are solved with various subjects of proving then, correspondingly, assessment of this circumstance is different. Very often, what is sufficiency for prosecuting party due to number objective and subjective reasons is not sufficiency for defence party.

According to article 145 of CPC, an inquiry officer, investigator, prosecutor, judge and jurors evaluate evidences on their inner conviction [25, p. 165], but the law does not disclose a content of the term "moral certainty". Interpretation of this term is also ambiguous in special literature dedicated to the problems of forensic psychological expertise. So, a number of authors (R.G. Ashkenazi, A.S. Barinov, I.N. Samokhin) are adhered an opinion that inner conviction should be considered as a method of assessment of evidences and like its result [1, p. 61; 2, p. 71; 21, p. 91-92]. Other authors (S.I. Vostrikov, I.G. Zotov, A.I. Zykov, S.I. Lyubimov) consider "moral certainty" not only like a method and result of evidences assessment, but also like a principle and criterion of evidences' evaluation $[7$, p. $51-52 ; 8$, p. $69 ; 12$, p. 51$52 ; 15$, p. 41].

Along with this, under method is understood a way of theoretical investigation or practical fulfillment of something [2, p. 71]. In this sense, moral certainty acts like an instrument of assessment of evidences on criminal case and the same time is a result of evaluation of evidences, i.e. acts as what has received in completion of any activity or work. In addition, it seems that when we are talking about proving in criminal process, inner conviction always acts as interim result. S.I. Nosov rightly notes that formation of moral certainty is not self-sufficiently: it acts as a base for adoption of decisions by any participants of investigation or court proceedings [17, $\mathrm{p}$. $71]$.

According to assertion of O.V. Rutintsev, indication of the law to moral certainty should be understood as exclusivity of competence of a person, carrying out 
criminal process $[20$, p. 32]. In our point of view, this definition is wrongly as each participant of criminal process acts according to his/her status, elements of which are correlated with status of other persons. Therefore, we take in base of our reasoning a definition of A.R. Ratinov, who determines an inner conviction "like a seeking of the truth, which is free from external coercion and not connected with formal instructions" [19, p. 167].

It is presented as interesting a characteristic of moral certainty given by Yu.K. Orlov, who distinguishes two signs of evidences assessment on inner conviction: a) first sign of free evaluation - this is disconnectedness of its subject with the law, absence any formal instructions in it and b) disconnectedness of a subject of assessment by an opinion of other subjects, prohibition interference in evaluating activity [18, p. 83].

One more sign of inner conviction is given by L.D. Kokorev, who emphasized that assessment of evidences by different participants of process, including high rank officials and bodies, has no mandatory significance for the consequent evaluation of evidences by investigators, judges and other persons carrying out a proving [13, $\mathrm{p}$. 224].

Resuming stated, E.A. Snegirev determines the inner conviction like free from opinions of other persons stable and morally substantiated mental attitude of subject of proving to quality and quantity of necessary and sufficient elements, which constitute a content of the notion of evidence and act as a method and result of evidences' (evidential information) assessment [22, p. 100].

As noted earlier, a lawmaker indicated in article 145 of CPC of Azerbaijan Republic that inner conviction should be based on comprehensive, complete and objective consideration of all assemblage of evidences. Similar formulation is considered to be right as term "circumstances of a case" that was used earlier is very indistinct, and in our opinion, insufficient concrete as in course of investigation and court proceedings are established the circumstances not a case, but criminally significant event: not a crime, since sometimes there may be answered whether crime was committed only after entering into legal force a verdict of guilty. They are 
established through formation of evidences, i.e. search, check and assessment of evidential information about indicated event. However not any information might further be transformed into evidences. Some information loses its evidential significance due to mistakes or omissions of investigative employers, who do not observe requirements of criminal procedural legislation.

According to article 145 of CPC, in course of evaluation of evidences an inquiry officer, investigator, prosecutor, judge and jurors have to be guided by law and their conscience. Earlier a lawmaker in article 66 of CPC of Azerbaijan Republic of 1960 as ground for evidences' assessment on inner conviction named legal conscience, a role of which in evaluation of evidences by a subject of proving is assessed ambiguous in literature. Particular, a number of authors (I.S. Furtsev, I.S. Scherbin) act against normative requirement to be guided with legal conscience under evidences' assessment as it is captured with requirement to evaluate evidences guiding by law [26, p. $77 ; 27$, p. 91-92].

At the same time, in opinion of other authors (A.I. Zykov), legal conscience is an important guiding step of evidences' evaluation as legal conscience of judges, prosecutors, investigators impacts on the fact how they are considering a significance of procedural law in proving, how they are interpreting such categories like "sufficiency of evidences for making of decision", "contradictions in evidences" etc. [12, p. 91-92].

In our point of view, one should not be refused from normative fixation of requirement of guiding with legal conscience under assessment of evidences, moreover, article 25.3 of CPC says about inner conviction and legal conscience. Under legal conscience in modern literature is understood a combination of imaginations, views, assessments and emotions, through of which are expressed the relation of people and public associations to valid law [5, p. 171]. This includes also valuable attitudes of certain person, his moral landmarks. Category of "conscience" is more related to philosophic categories, it has many aspects, is interpreted ambiguous and therefore its using in criminal procedural law is wrong. 
Now, we will try to consider the problems with concrete samples, to correlate them with stated above provisions and to offer the ways for resolution of paradox situations.

On September 2010 Kurdamir District Police Department (hereinafter, DPD) received a complaint of parents of a minor Ismaylov, 2003 year of birth about forcible actions of sexual nature in respect of him by their neighbour Nuriyev, 1960 year of birth, who had a family and children. On 27 September 2010 as result of checking their application, there was instituted criminal case on signs of article 150.3.3 Criminal Code of Azerbaijan Republic

According to testimonies of a minor Ismaylov, on 4 September 2010 his neighbour Nuriyev by fraudulently brought him to a garden, where under ladder forcible conducted sexual actions then took him home, where had continued them, and his sister Aytaj had saw everything happened.

In the following interrogations Ismaylov stated that Nuriyev did the actions of sexual nature also earlier, brought him by car out of town.

Interrogated Nuriyev denied commission of crime and had stated that was a victim of slander. Questioned Ismaylova Aytaj confirmed that she saw like Nuriyev brought her minor brother to a garden, conducted sexual actions and then came him to home.

On 21 October 2010 an investigator of Kurdamir DPD ordered on a case forensic-psychological expertise of minor I. Ismaylov and submitted the question about presence to the latter inclination to factorization, disorder in development and ability adequacy perceive, remember, understand and reproduce happened events.

An expert received material of a case and I. Ismaylov in person.

According to report no. 15301 dated on 22 October 2010, an expert gave a reference to observe requirements of articles 97 and 269 of CPC and article 297 of Criminal Code of Azerbaijan Republic.

As it known, article 97 determines a status of the expert, and article 269 of CPC says about conducting of expert examination in expert institution [25, p. 113-115; 
288]. Article 297 of Criminal Code says about criminal responsibility of the expert for giving obviously false report [24, p. 168].

Furthermore is noted that the report made on 24 November 2010.

Chapter "Brief content of a case" verbatim stated a content of descriptive part of decision, questions put before the expert, data of the expert.

Here also indicated that expert examination began on 25 October 2010, after that an investigator was requested to deliver minor I. Ismaylov for examination.

Further is noted that in course of preparation of the expert report there were used the following special sources and books: 1) B.H. Aliyev. Problems of forensicpsychological expert examination in criminal and civil process. Baku, 1996; 2) A.A. Alizadeh. Sex education of children and teenagers. Baku, 1987; 3) S.F. Shabanov, Ya.R. Shekiyev. Explanatory dictionary of terms of forensic-psychological expert examinations. Textbook of methods. Baku, 2004; 4) S.F. Shabanov. Organization and production of forensic-psychological expert examinations on cases about sex crimes. Textbook of methods. Baku, 2002; 5) Burlachuk L.F., Morozov S. Dictionary-guidance on psycho-diagnostics. S. Petersburg: Piter, 2000; 6) Kon I.S. Introduction to sexology. M., 1987; 7) Nagayev V.V. Fundamentals of forensicpsychological expert examination. M., 2000; 8) Safuanov F.S. Forensic psychological expert examination in criminal process. Scientific practical textbook. M., 1998; 9) Medicine and forensic psychology. Ed. by T.B. Dmitriyeva, F.S. Safuanov. M., 2005.

Descriptive part of the report is stated circumstances of the case, indicated in investigator's decision, pointed out that in course of investigation were used the following methods: psychological interlocution-interview; interview; biographic (anamnesis) method; thematic apprentice test; plot pictures; drawing of tree; fourth is odd; reminiscence on images; ten words; what is lost; determination of main signs; classification and comparison of notions; identification of figures.

Further, there are verbatim stated testimonies of interrogated persons (I. Ismaylov, his sister and mother, Nuriyev), is noted that in certain dates (08.11.2010) were made expert-psychological records, retelling content of the references, forensic- 
medical expert examination and other documents, which were received in course of investigation, and according to questions of investigator are made preliminary conclusions.

Operative part is indicated that a) inclination of Ismaylov to factorization was not found; b) mental disorder of Ismaylov was not discovered and c) Ismaylov adequacy perceives and reproduces conducted in respect of him actions, but does not understand their content.

On 5 November 2010 investigator ordered forensic psychological examination and submitted to the expert the same questions in respect of Aytaj Ismaylova and on 8 December 2010 was received the report of expert-psychologist no. 16122.

Content of both reports was the same if not to consider that in compliance with the report no. 16122, unlike her brother A. Ismaylova had understood (realized) the nature of committed in respect of him actions and the fact that first report has been spoken in the second one.

Thus, the two conclusions show that the experts using the same methods came to different conclusion about adequate understanding of the events by examined persons: I. Ismaylov did not understand their nature, but his sister had understood, though age difference between them was less than two year.

It seems that used methods and special literature say not much to investigator, who investigated criminal case no. 58086 and also many other participants of this process, another investigators and prosecutors.

Meanwhile, under adversarial process on this case and certain preparedness its participants, who are able to raise doubts of court and other participants of court proceedings and even to prosecuting party. For example, why in course of expert examinations were applied methods indicated in the report, but not the tests of R. Amthauer, matrices of D. Raven, scale of Wechsler, board of Seguin, questionnaire of S. Hathaway, methods of V. Milman, J. Rotter, J. Rix, W. Stefanson, O. Ademiller and many others.

Or, why the works of B.H. Aliyev, V.V. Nagayev and F.S. Safuanov were used as special literature, but there were not used the works of Yu.M. Antonov, R.G. 
Ashkenazi, I.A. Buzhanidze, A.A. Gorin, V.S. Gorin, V.S. Egorov, A.I. Zykov, B.D. Karvasarsky, M.V. Kostsitsky, M.M. Kochenov, I.A. Kudryavtsev, A.V. Kudryavtseva, V.V. Melnik, Yu.T. Myasnikov, V.T. Nop, A.M. Stolyarenko, V.S. Magun, E.R. Rossinskaya, T.M. Sekerazh, O.D. Sitkovskaya, G.P. Trifonova, E.N. Kholopova, Yu.V. Chufarovsky, S.S. Shipshina and other Russian and other countries scientists.

In certain situations there will be a question a usage by the expert S.F. Shabanov his works and also using his works by subordinated employers.

As we stated above, the point of view of V.V. Nagayev, F.S. Safuanov, I.A. Kudryavtsev and other scientists concerning to number of problems of forensic psychological examination are not coincide, and in number of cases diametrically contrary. Therefore, the question is why were taken ideas of F.S. Safuanov, and ignored, e.g. I.A. Kudryavtsev's one.

This is one side of problem, which connected with assessment of an expertpsychologist's report, but other one is concluded in the fact that an investigator has no alternative choice in this matter. He needs to accept conclusions of an expert, but it so good if they do not contradict other evidences, and to accept them as unconditional.

An investigator is not able to dispute the conclusions of the expert since he does not know in special matters; if he knows special matters then he has no an opportunity to dispute them since there is nowhere in Azerbaijan, except Centre of Forensic Examinations, are not conducted. Repeated and commission examinations will be conducted in the same Center by the same specialists, who are accountable to one the same head.

Thus, there is created such situation, when investigator has to accept a report of forensic psychological examination as unconditional evidence some circumstances.

But, in this case, when there are no contradictions between evidences, otherwise all collisions of legislation, about which we spoke above, are appeared. 
How can inner conviction be formed to investigator or judge, if they are not familiarized with works of F.S. Safuanov, do not know special knowledge and about availability of other methods?

So, from 150 interviewed persons (on 30 investigators, judges, inquiry officers, prosecutors and lawyers) on question, how they carried out assessment of forensic psychological examination report, they answered (considered all responds) that take conclusions of the expert as basic one, make comparison with other evidences, use special knowledge, study special literature and apply to independent specialists. 24 judges, 26 investigators, 28 prosecutors, 28 inquiry officers and 30 lawyers pointed out additionally that in number of cases use interrogation of experts.

Own special knowledge have no evidential force, and applying to independent specialists in impossible due to absence of these and impossibility to involve them in process. Therefore, they have to apply to specialists (experts) as they have no necessary knowledge.

With regards of comparison to other evidences, it seems that priority will be given to the report of forensic psychological examination, as otherwise process is disorganized and to substantiate refusal from the report of forensic psychological examination will be impossible.

In the last case, contradictions will be remained in materials of a case, which will be ground for objections of opposite party.

If come back to considered example to minor Ismaylov, then we see that in numbers of cases the report of forensic psychological examination contraries to materials of criminal case. So, experts came to conclusion that minor Ismaylov had not realized nature the actions, which were committed in his respect, and the sister understood. However both minors did not cry and called for help.

Minor I. Ismaylov during sexual actions saw that his sister was watching him and told this accused Nuriyev, and he had not react and continued sexual actions in home.

This behaviour is seemed to be inadequate, or assertions of victim and his sister are wrong. 
But in course of investigation nobody, except a defender, paid attention to these circumstances as upon assignment of forensic psychological examination prosecuting party was only interested in inclination of I. Ismaylov to factazation.

Let's image the situation that experts-psychologists determined inclination of victim and his sister to factazation, their incapability to perceive, understand and reproduce event happened. What would it be changed? In any cases, investigator would have to establish a fact of crime and its circumstances, and state of victims and witnesses have indirect significant, which are necessary to check other evidences.

Thus, in matters of forensic psychological examination we can distinguish an evidential aspect, when a report of expert-psychologist has evidential value or has no such one, i.e. it is an alternative and has to a core of main element of proving subject (happened or not criminal accident) indirect relation.

But, report of forensic psychological examination has crucial significance for solution of criminal legal matters, when upon absence of birth documents is determined an age of accused person.

In connection with stated, we may make conclusion that under solution of criminal legal matters a report of forensic psychological examination is constitute part of combination of equal evidences, assessing under rule of article 145 of CPC, and, upon absence of this combination and solution of criminal legal objectives, is the main one.

However, this contraries to provisions of article 33.3 of CPC and does not answer at main question about legitimacy of evaluation expert's conclusion by incompetent participants of process.

This matter might only be solved with increasing of special knowledge level (not only psychological one) all participants of process, first of all, to a court as it is one of the main conditions of justice court proceedings at all its stages.

In modern foreign literature dedicated to problems of psychological examination has repeatedly expressed idea that expert-psychologist's report can only be refuted by other expert psychologist of higher qualification. 
Moreover, it was expressed suggestions to exclude a report of expertpsychologist from evidences, limiting its significance only with orienting factors since, as rule, conclusions of the expert-psychologists on cardinal matters of criminal process are subjective, depending on research methods applied and might be with equal success defended the opposed point of views at the same issue [28, p. 60-62].

In our point of view, assertion on possibility refutation of conclusions of expertpsychologist only other expert (specialist) higher qualification is wrong and uncompleted, i.e. a matter about qualification level might not be determined with diplomas or certificates or length of work. In addition, level of qualification does not guarantee compliance expert-psychologist's conclusions to the truth. In this situation dispute about trueness of conclusions might be lasted endlessly and continued with appearance new expert of higher qualification.

In work of J. de Keyser and Hank Elfers "Understanding of reports of forensic examinations by judges, defenders and court employers" is pointed out that most part of judges and defenders are taking the conclusions of experts-psychologists as a basis not going deeply into correctness of examinations made and not understanding clarifications in this part, which are stated in court sessions.

Moreover, sometimes judges are ignoring the reports of forensic psychological examinations rejecting them with common words not confirmed with actual circumstances of case [30, p. 191-207].

The same conclusions are made in work "Psychological Evaluations for the Courts” by Harry B. Melton, John Petrila, Norman G. Poythress [29, p. 175-179], "Psychological Expertise in Court" by Daniel A. Krauss, Joel D. Lieberman [31, p. 98-101] and "Psychological Sciences in the Courtroom. Consensus and Controversy" by Jennifer L. Skeem, Kevin S. Douglas and Scott O. Lilienfeld [32, p. 217-230].

Suggestions of foreign specialists on solution of problem are similar to ours: only increasing of level of special psychological knowledge of judges and other participants of process enable to provide justice in full meaning of this word. 


\section{References}

1. Ashkenazi R.G. Problemy otsenki zaklyucheniya ekspert-psikhologa [Problems of assessment of expert-psychologist's report]. Moscow, 2010, 267 p.

2. Barinov A.S. Psikhologicheskaya ekspertiza v ugolovnom sudoproizvodstve [Psychological expertise in criminal proceedings]. Tula, 2010, $311 \mathrm{p}$.

3. Belkin R.S. Sobiranie, issledovanie i otsenka dokazatelstv. Suschnost' i metody [Collection, investigation and evaluation of evidences. Core and methods]. Moscow, 1966, 295 p.

4. Belkin A.R. Teoriya dokazyvaniya [Theory of proving]. Moscow, 1999, 429 p.

5. Bakhtin I.S. Struktura nauchnogo poznaniya [Structure of scientific cognition]. Tver, 2009, 326 p.

6. Bukhanovsky A.O., Kutyavin Yu.A., Litvak M.E. Obschaya psikhopatologiya General psychopathology]. Rostov-n/Don, 1998, 411 p.

7. Vostrikov S.I. Problemy naznacheniya psikhologicheskikh ekspertiz v ugolovnom protsesse [Issues of assignment of forensic psychological expert examinations in criminal process]. S.Petersburg, 2009, 306 p.

8. Epischev A.S., Zotov I.G. Problemy sudebno-psikhologicheskoy ekspertizy [Problems of forensic psychological expert examination]. Kaliningrad, 2010, 311 p.

9. Zavidov B.D. Zalyuchenie eksperta i ego otsenka sledovatelem [Expert's report and its assessment by investigator]. Sledovatel'. 1998, no. 9, pp. 40-42.

10. Zolotova A.I., Shmelev I.M. Rukovodstvo po rassledovaniyu ubiystv [Guidance on murders' investigation]. Moscow, 2007, 411 p.

11. Zosintsev I.F., Kraynov I.G. Rassledovanie ubiystv [Investigation of murders]. Volgograd, 2007, 411 p.

12. Zykov A.I. Sudebno-psikhologicheskaya ekspertiza v dosudebnom proizvodstve [Forensic psychological expert examination in pre-trial production]. S. Petersburg, 2010, 296 p.

13. Kokorev L.D., Kuznetsov N.P. Ugolovny protsess: dokazatel'stva i dokazyvanie [Criminal process: evidences and proving]. Voronezh, 1995, 268 p. 
14. Kommentariy k paradoksam UPK Azerbaijanskoy Respubliki. (Chast' 1). Pod red. Suleymanova J.I. [Commentary to paradoxes of the CCP of Azerbaijan Republic (part 1), ed. by Suleymanov J.I.]. Sbornik nauchnykh statey [Col. sci. articles]. Baku, 2004, 120 p.

15. Lyubimov S.I. Psikhologicheskaya ekspertiza pri rassledovanii prestupleniy [Psychological expertise under investigation of crimes]. Moscow, 2009, 287 p.

16. Nadgorniy G.M., Isaakovich B.M. Zaklyuchenie eksperta i ego otsenka v ugolovnom protsesse [Expert's report and its assessment in criminal process]. Sb.: Kriminalistika i sudebnaya ekspertiza [Col.: Criminalistics and forensic expert examination]. Kiev, 2001, no. 50, pp. 91-95.

17. Nosov S.I. Psikhologicheskaya ekspertiza: problemy naznacheniya i otsenki vyvodov [Psychological expertise: problems of assignment and assessment of conclusions]. Volgograd, 2009, 311 p.

18. Orlov Yu.K. Osnovy teorii dokazatel'stv v ugolovnom protsesse [Basis of theory of evidences in criminal process]. Moscow, 2000, 138 p.

19. Ratinov A.R. Sudebnaya psikhologiya dlya sledovateley [Forensic psychology for investigators]. Moscow, 2001, 352 p.

20. Rutintsev O.V. Psikhologicheskaya ekspertiza kak sredstvo dokazyvaniya [Psychological expert examination as means of proving]. Volgograd, 2008, $176 \mathrm{p}$.

21. Samokhin I.N. Psikhologicheskaya ekspertiza v ugolovnom protsesse [Psychological expert examination in criminal process]. Moscow, 2010, 206 p.

22. Snegirev E.A. Otsenka dokazatel'stv po vnutrennemu ubezhdeniyu [Assessment of evidences on moral certainty]. Dis... kand. yurid. nauk [PhD in Law Diss.]. Voronezh, 2002, 198 p.

23. Solovyev A.B. Protsessual'nye i takticheskie osnovy doprosy na predvaritel'nom sledstvii [Procedural, psychological and tactical basis of interrogation in preliminary investigation]. Moscow, 2002, 192 p.

24. Ugolovniy kodeks Azerbaijanskoy Respubliki [Criminal Code of Azerbaijan Republic]. Baku, 2007220 p. 
25. Ugolovno-protsessual'niy kodeks Azerbaijanskoy Respubliki. Po sostoyaniyu na avgust 2014 g. [Code of Criminal Procedure of Azerbaijan Republic, as for August 2014]. Baku, 2014, 568 p. [in Azerbaijani].

26. Furtsev I.S. Problemy otsenki i ispol'zovaniya zaklyucheniya eksperta [Problems of expert's evaluation of report and using]. Volgograd, 2009, 311 p.

27. Scherbin I.S. Spetsial'nye znaniya v ugolovnom sudoproizvodstve [Special knowledge in criminal proceedings]. S. Petersburg, 2010, 386 p.

28. Bruce A Stevens. Crossfire: how to survive giving expert evidence as a psychologist. Bowen Hills, Qld.: Australian Academic Press, 2008, 94 p.

29. Gary B. Melton, John Petrila, Norman G. Poythress and more. Psychological Evaluations for the Courts. The Guilford Press, New York, USA, 2007, 930 p.

30. Jan de Keijser, Henk Elffers. Understanding of forensic expert reports by judges, defense lawyers and forensic professionals. Psychology, Crime \& Law. Vol. 18, no. 2, 2012, pp. 191-207.

31. Psychological Expertise in Court. Vol. 2. Edited by Daniel A. Krauss, Joel D. Lieberman. Las Vegas, USA, 2009, 204 p.

32. Psychological Sciences in the Courtroom. Consensus and controversy. New York, Guilford Press, 2009, 614 p. 